\title{
特許出願における拒絶理由通知対応
}

青木 一男 $* * * *$

\begin{abstract}
Journal of The Japan Institute of Light Metals, Vol. 66, No. 4 (2016), 185-191
(C) 2016 The Japan Institute of Light Metals
\end{abstract}

\section{File a response to an office action in a patent application}

\author{
Kazuo AOKI*,**
}

Keywords: office action, patent application, patent law

\section{1. はじめに}

一般社団法人軽金属学会編集委員会加一般社団法人日本 アルミニウム協会特許委員会（表 1）に対して, 研究者・技 術者を対象とした特許に関する記事の執筆依頼を頂いていま す。昨年度は，「特許出願と技術流出」との夕イトルで執筆 しました。今年度は, 特許庁から送付される拒絶理由通知書 への対応に関して, 研究者・技術者向けにわかりやすく説明 します。この記事により，会員の皆様に「拒絶理由通知対応」 の一端でもご理解頂けましたら幸いに存じます。

\section{2. 特許制度}

\section{1 特許制度の意義}

発明は，目に見えない無体物です。家や車などの有体物の ように目に見える形で誰かが占有できるものではありませ ん。したがって，法律などの社会的なルールによって発明が 保護されなければ，発明者は自分の発明を盗まれないように 秘密にしておこうとするでしょう。しかしそれでは，発明者 もその発明を有効に利用できないばかりか, 他人が同じよう な研究・投資をすることになってしまいます。

そこで, 特許制度は, 発明者には, 一定期間, 一定の条件 のもとに独占排他権を与えて, 発明の保護を図る一方, その 発明を公開して利用を図ることとしています。その特許の権 利期間が切れた後, 誰でもその発明を自由に実施できること として，新しい技術を人類共通の財産としながら，技術の進

表 1 特許委員会委員 (2015 年 10 月現在)

\begin{tabular}{|c|c|c|c|}
\hline 委員長 & 本川 & 治己 & 株式会社神戸製鋼所 \\
\hline 委 員 & 横井 & 慶一 & 昭和電工株式会社 \\
\hline & 稲林 & 芳人 & 株式会社UACJ \\
\hline & 小林 & 智昭 & 三菱アルミニウム株式会社 \\
\hline & 青木 & 一男 & 日本軽金属株式会社 \\
\hline 事務局 & 石川 & 龍男 & 一般社団法人日本アルミニウム協会 \\
\hline
\end{tabular}

歩を促し, 産業の発達に寄与しようというものです ${ }^{1)}$ 。特許 法第一条は，以下のように法目的を規定しています。

「この法律は，発明の保護及び利用を図ることにより，発明 を奨励し，もつて産業の発達に寄与することを目的とする。」

2003 年 3 月，当時の小泉内閣は，わが国が知的財産立国を 目指すために, 知的財産戦略本部を設置し, 特許の活用を推 進することを提唱しました。図 1 に知的創造サイクルとその 波及効果 ${ }^{2)}$ を示します。

\section{2 特許法上の発明}

ここで，特許法上の発明とは，一体どのようなものなので しょうか。特許法第二条は, 以下のように発明を規定してい ます。

「この法律で「発明」とは, 自然法則を利用した技術的思想 の創作のうち高度のものをいう。」

・自然法則を利用

「自然法則」とは, 自然界において経験的に見出される科 学的な法則を言います。また，「利用」とは, 一部に利用し ないものがあっても全体として利用していればよく, 同一結 果を反復できることを言います。

•技術的思想

「技術」とは, 一定の目的を達成するための具体的手段で あって, 実際に利用でき, 知識として伝達できるものを言い,

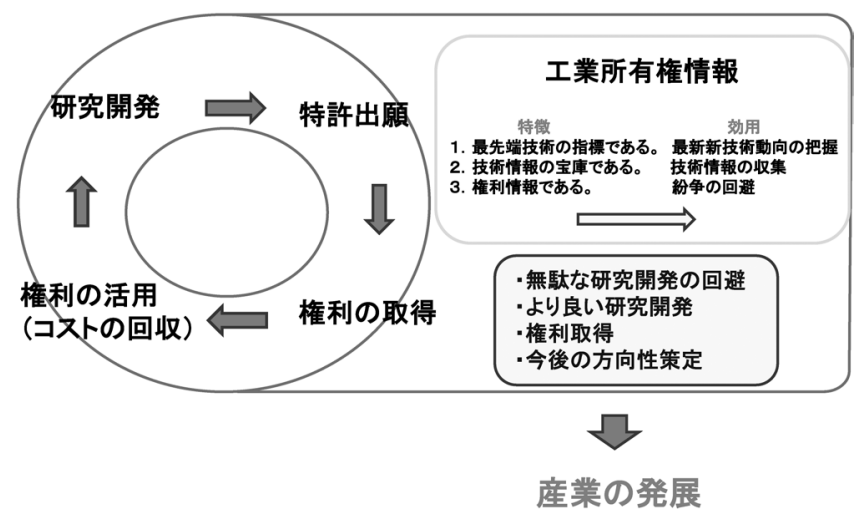

図1 知的創造サイクルとその波及効果 ${ }^{2)}$

*一般社団法人日本アルミニウム協会＼cjkstart特許委員会 Patents Committee, Japan Aluminum Association

**日本軽金属株式会社 知的財産権部（广421-3291 静岡県静岡市清水区蒲原 1-34-1） Nippon Light Metal Co., Ltd. (1-34-1 Kanbara, Shimizu-ku, Shizuoka-shi, Shizuoka 421-3291) E-mail: kazuo-aoki@nikkeikin.co.jp

受付日：平成27年 12 月 3 日 受理日：平成 27 年 12 月 16 日 
個人の熟練によって得られる技能とは異なります。

·創作

「創作」とは，新しいことを創り出すこと，自明でないこ とを言いますので，何も作り出さない「発見」とは区別され ます。

•高度

発明は，自然法則を利用した技術的創作であっても，「高 度」なものでなければなりません。

\section{3 特許を受けることができる発明}

特許法上の発明に該当していても，すべての発明が特許を 受けられるわけではありません。特許を受けるためには，特 許法で定める「特許を受けることができる発明」の条件を満 たす必要があります。この条件のことを「特許要件」と言い ます。図2に特許法に定められている特許要件を示します ${ }^{1)}$ 。 そして,「特許要件」を満たしているか否かを判断する時点 は, 特許出願の時点です。

2.3.1 産業として実施できるか（特許法第29条柱書き） 特許を受けることができる発明であるためには，産業とし て実施できなければなりません。これは，ただ単に学術的・ 実験的にしか利用できない発明は, 特許法の法目的を達成す ることができず，保護する価值がないからです ${ }^{1)}$

産業として実施できることを，「産業上の利用可能性があ る」とも言います。そもそも産業とは, 工業, 鉱業, 農業, 林業, 漁業, 水産業, 牧畜業, 交通業, 運輸業等を含みます。 また，最近ではビジネスモデル特許に見られるように，保険 業，金融業等のサービス産業をも含むと考えられます ${ }^{3)}$ 。

発明が産業の発達に寄与する可能性さえあれば，その発明 は産業上の利用可能性があると考えられます。ただし，医療 業 (医療行為) については産業上の利用可能性がない, と解 するのが現在でも通説となっています。これは，特許権の効 力が医療行為に及ばないようにするという趣旨です。また, 実際上，明らかに実施できないもの，例えば，赤外線反射 フィルムで地球全体を覆う方法などは産業上の利用可能性が ないと言えます。

2.3.2 新しいかどうか（特許法第29条第 1 項） 特許を受けることができる「発明」は，今までにない「新

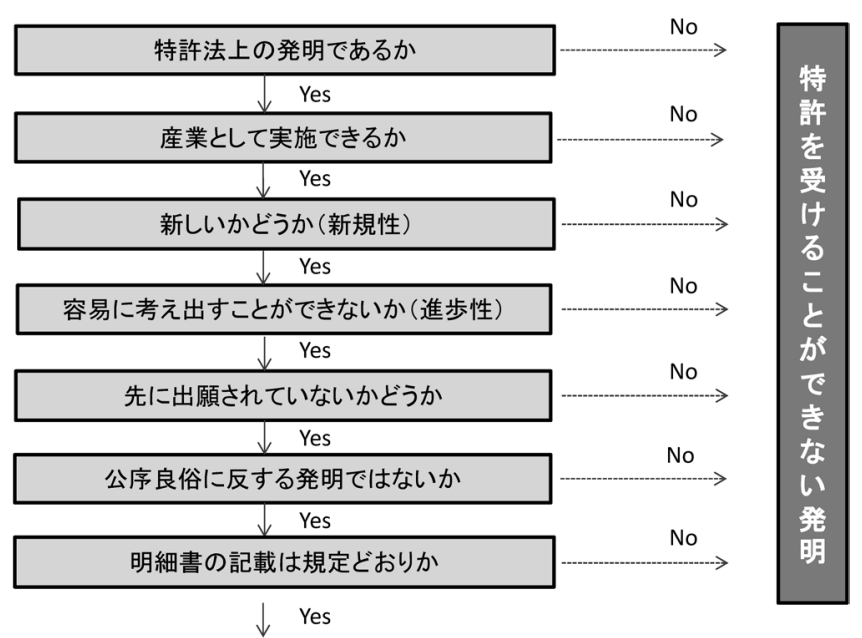

特許を政けることがてきる筧明

図2 特許を受けることができる発明 ${ }^{1}$
しいもの」でなければなりません。すでに誰もが知っている ような発明に特許権という独占権を与えることは, 社会に とって百害あって一利もないからです ${ }^{1)}$

この新しさのことを「新規性」と言います。例えば，「そ の発明に新規性がある」という場合, その発明が世の中にま だ知られていないことを意味します。

また,「新規性」を判断する際の地域は, 日本国内のみな らず，外国も含まれます。外国で知れわたった技術も「新規 性」を判断する際の対象となります。

特許法では, 新規性が欠如しているために特許を受けるこ とができない発明として, (1)「公然知られた発明」, (2)「公 然実施をされた発明」, (3)「頒布された刊行物に記載された 発明」, (4)「電気通信回線を通じて公衆に利用可能となった 発明」が列挙されています。

特許法では，これら列挙した発明を除き，その発明につい て特許を受けることができる規定となっています。

それでは, 特許庁における審査では,「新規性のありなし」 を一体どのようにして認定するのでしょうか。

特許庁では，特許出願の審査の一環として，審査の対象と なる特許出願の出願前に日本国内または外国において公開さ れた刊行物を調査しています。この調査のことを先行技術調 査と呼びます。この先行技術調査では，発行日が明確である 刊行物，例えば，公開特許公報等を対象としています。

先行技術調査の結果, その特許出願に係る「発明」を開示 している刊行物が見つかれば，その発明は，「新規性なし」 と認定されます。しかし，その特許出願に係る発明を開示し ている刊行物が見つからなければ，その発明は「新規性あり」 と認定されます。

後述する拒絶理由通知では，この刊行物を引用文献（引用 例）と呼び, この引用文献に記載された発明のことを「引用 発明」と言います。ただし, 引用文献が公開特許公報等であ る場合, 引用発明は, 特許請求の範囲に係る発明以外に, 明 細書, 図面に記載された発明も対象となります。

2. 3.3 容易に考え出すことができないか（特許法第29条 第2 項)

新規な発明であっても，従来技術をほんの少し改良しただ けの発明のように, 容易に考えつく発明については, 特許を 受けることができません。容易に考え出された発明でも独占 排他権である特許権が認められるようになると, 技術の進歩 の妨げとなるからです ${ }^{1)}$ 。

この容易に考え出すことができないことを「進歩性があ る」と表現します。例えば，「その発明に進歩性がある」と いう場合, その分野の通常の知識を有する者 (当業者) がそ の発明を容易に考え出すことができないことを意味します。

特許法では，前項で列挙した発明(1)〜(4)に基づいて，当業 者が容易に発明をすることができたときは，その発明につい ては，特許を受けることができない規定となっています。

それでは, 特許庁における審査では, 「進歩性のあり/なし」 を一体どのようにして認定するのでしょうか。

先行技術調査の結果, その特許出願に係る発明に「最も近 い発明」を開示している刊行物が見つかったとします。特許 庁の審査官は, その特許出願に係る発明と引用発明とを対比 して, 一致点・相違点を明らかにします。そして, 出願当時 の技術水準に照らして, 当業者が引用発明および出願時の周 
知技術等から，その特許出願に係る発明に想い至ったか否か の「論理づけ」を試みます。この結果，「論理づけ」ができ た場合はその特許出願に係る発明の進歩性は否定されます が，「論理づけ」ができない場合はその特許出願に係る発明 の進歩性は否定されず，「進歩性を有する発明」と認定され ます4)。

2.3.4 先に出願されていないか（特許法第39条および特 許法第29条の2)

特許権は独占排他権ですので，2つ以上の同じ特許権が併 存することは許可されるべきではありません。わが国では, 同一の発明について，異なった日に2つ以上の出願がされた 場合，先に特許庁に出願した者に特許を与えています。これ を「先願主義」と言います ${ }^{11}$ 。

2.3.5 公序良俗に反する発明でないか（特許法第 32 条）

国家社会の一般的な道徳や倫理に反する発明や，国民の健 康に害を与えるおそれのある発明は，公益的見地から特許を 受けることができません ${ }^{1)}$ 。

2.3.6 出願書面の記載は規定どおりか（特許法第36条お よび特許法第 37 条)

特許を受けるためには, 特許権の付与を求める意思表示と して特許出願をしなければなりません。現物により発明を特 定する方法は保存等において不便であり， 口頭による方法で は客観的に発明を特定することが困難であるため，書面によ り特定する方法を採用しています ${ }^{1)}$ 。したがって，特許出願 では，所定の書面を特許庁に提出する必要があります。所定 の書面とは，願書，明細書，特許請求の範囲，図面および要 約書です。

願書とは, 出願人, 発明者, 代理人等の書誌事項を記載し た書面のことです。

明細書とは，特許を受けようとする発明についての詳細な 説明を記載した書面のことです。特許を受けるためには，具 体的にどのような発明をしたのか，当業者が読んで実施でき る程度に発明の内容を明らかにする必要があります。した がって，明細書は，当業者がその発明の実施ができる程度に 明確かつ十分に記載する必要があります。

特許請求の範囲とは，特許を受けようとする発明を技術的 な範囲として請求項（クレーム）というひとつの文で表現し たものです。特許請求の範囲に含まれる請求項はひとつだけ とは限らず，複数の請求項が含まれる場合もあります。特許 を取得した場合に，この特許請求の範囲が権利範囲となりま す。したがって，特許請求の範囲は，特許を受けようとする 発明について簡潔明瞭に記載する必要があります。

図面は，明細書だけでは特許を受けようとする発明を十分 に説明できない場合に，使用します。

要約書は，特許を受けようとする発明の要約を記載してい ます。

図 2 に示すとおり，特許法によると，上記の特許要件をす べて満たす出願に特許が付与されることになっています。こ れに対して，上記の特許要件のうちひとつでも満たさない出 願は，拒絶理由を有することになります。この拒絶理由が解 消しない限り，最終的には拒絶査定となります。そして，拒 絶査定が確定すると，特許は付与されません。

\section{4 特許を取得するための手続き}

それでは，特許を取得するには，どのような手続きが必要
なのでしょうか。

特許法では, 特許出願（特許法第 36 条）, 出願公開（特許 法第 64 条), 出願審査の請求 (特許法第 48 条の 3 ), 拒絶査 定 (特許法第 49 条), 特許査定 (特許法第 51 条) 等について 定めています。図3に特許出願から審査, 査定までのフロー チャートを示します。

2.4.1 出願公開

図 3 に示すとおり，特許出願から 1 年 6 か月で出願公開と

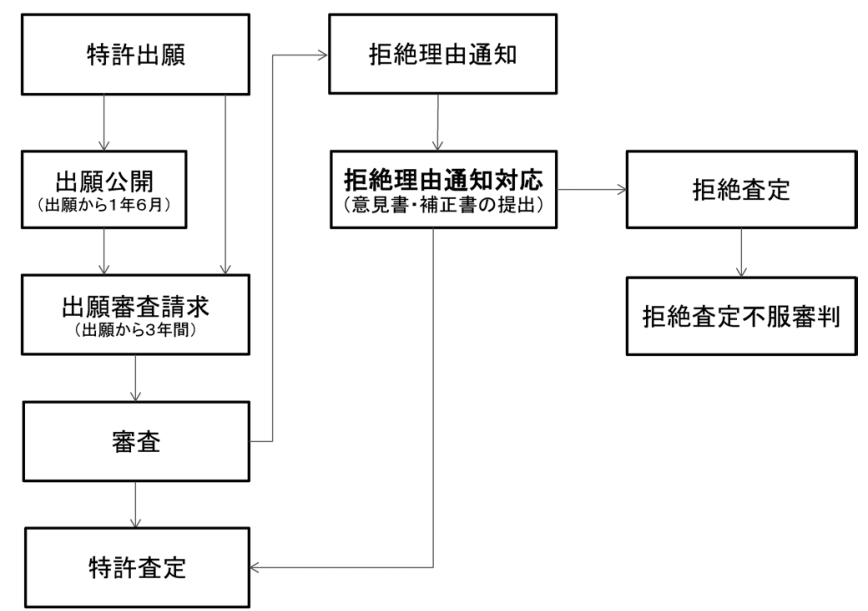

図3 特許出願から審査, 査定までのフローチャート

JP 2008-38495 A 2008.2.21

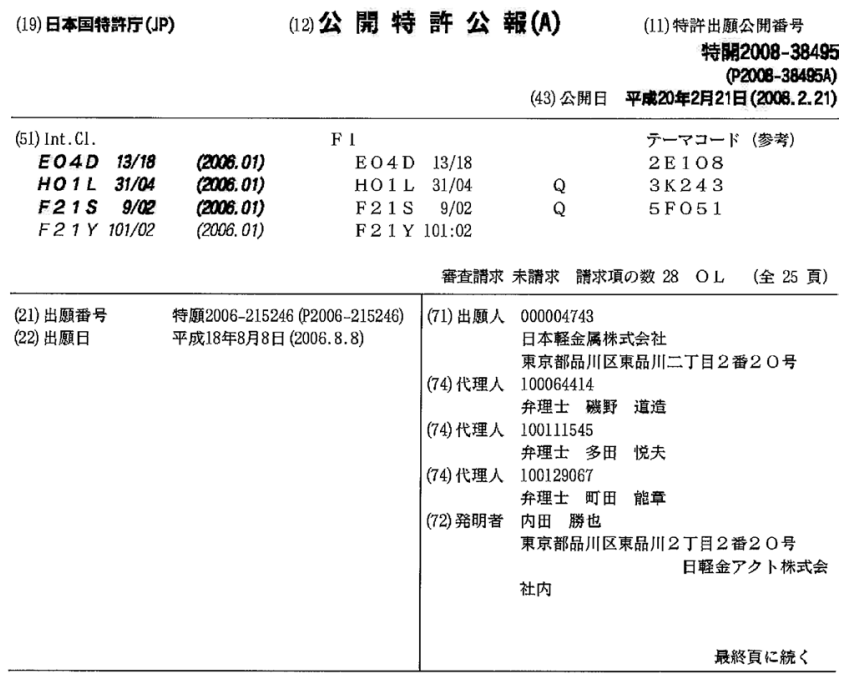
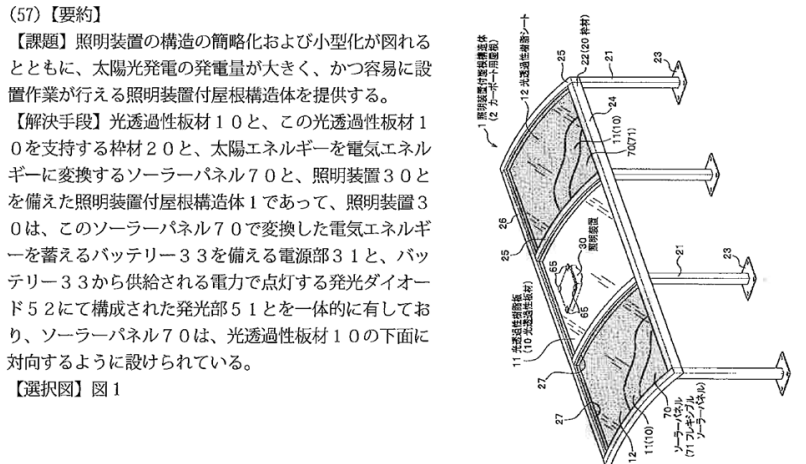

図4 公開特許公報のフロントページ具体例 
なり，公開特許公報が発行され，特許出願の内容が公開され ます。図4に公開特許公報の実例注1 を示します。

\section{4.2 出願審査の請求}

特許出願について審査が必要であれば，出願から 3 年以内 に出願審査の請求を行います。この出願審査の請求をせずに 放置すると, 出願から 3 年経過後にその特許出願は取り下げ られます。そうなると, 出願そのものがなかったことになり ます。

出願審査の請求後, 通常は $1 \sim 2$ 年経過すると, 審査が開 始されます。この審査を行うのが，特許庁の審査官です。図 3 に示すとおり, 審査の結果, その特許出願が特許査定とな る場合と，拒絶査定になる場合があります。

\section{3. 拒絶理由通知}

この拒絶理由通知とは, 一体どのようなものなのでしょうか。 特許出願は技術分野ごとに審査されます。そして, 特許出 願の審査の結果,「拒絶理由を有しない」と認定された場合, その出願は特許査定されます。

それでは，審査の結果，「拒絶理由を有する」と認定され た場合，その出願はどのようになるのでしょうか。このよう な場合，いきなり拒絶査定という行政処分が下されると，出 願人にとって不利益となります。そこで，出願を審査した審 査官は，拒絶理由通知書という書類を作成して出願人に送付 します。

この通知の意味するところは，「この出願には現在，拒絶 理由が存在するため, このままの状態で特許査定にはできま せん。適切に対応して拒絶理由を解消してください。」とい うことです。拒絶理由通知書における認定理由の箇所は, 請 求項ごとに 1 2 行程度とかなり簡潔に記載されている場合 がほとんどでした。最近では，認定理由の箇所の記述が非常 に丁寧な拒絶理由通知書も見受けられます。

拒絶理由通知を受け取った出願人は, 意見書, 手続補正 書（以下，「補正書」という。）という書面を作成して，所定 期間内に特許庁へ提出します。

意見書，補正書を受け取った審査官は，出願人の意見等を 考慮して, 再度審査を行い, 特許査定又は拒絶査定を下します。

\section{4. 拒絶理由通知対応}

\section{1 具体的手続き}

この拒絶理由通知に対して，出願人側は，所定期間内に意 見書, 補正書等の応答書類を特許庁に提出して応答します。 これが「拒絶理由通知対応」といわれるものです。

意見書は，拒絶理由について出願人の意見を述べる書面で あり，拒絶理由通知書において認定された拒絶理由が存在し ない旨，あるいは拒絶理由が解消している旨を述べます。

補正書は，補正の内容を具体的に書面としたもので，特許 請求の範囲（請求項）等を補正する必要のある場合の久提出 します。特許請求の範囲等の補正は, 出願当初の明細書, 特 許請求の範囲または図面に記載された事項の範囲内で可能です。

これら意見書等を所定期間内に提出しない場合には，本特 許出願は自動的に取り下げとなりますので，注意が必要で す。どのように応答するかによっても，取得できる権利範囲 の広狭が決まってきますので, 出願人にとって, 拒絶理由通 知対応は疎かにできないものとなっています。

\section{2 検討事項}

拒絶理由通知書が届いた場合に，検討すべき事項は，以下 の通りです。

（1）審査官の認定をよく理解すること。

（2）引用文献に記載の発明をよく理解すること。

（3）本願発明をよく理解すること。

上記（1）～(3) を検討する際の重点の置き方については, ケース・バイ・ケースです。例えば, 検討の当初は, 審査官 の意図がまったく理解できないこともよくあります。しか し，少なくとも（1）と同時に（2），（3）を実行することで, 拒絶理由への対処法の大筋は見えてくる場合が多いかと思い ます。

通常は，（1）審査官の認定をよく理解すること，を実行す ることが，拒絶理由をかわすための近道です。拒絶理由通知 書と引用文献を見ただけで，短時間に解決策が見えることも あります。審査官がある「筋書」を想定して拒絶理由通知書 を作成した場合は, 出願人にも, この「筋書」がわかる場合 もあります。

審査官の認定理由の文面は様々ですが，どのように応答す ればよいのか，その具体的方法を示唆してくれるものもあり ます。そして，そのような示唆も参考になることがしばしば あります。ただし，そのような示唆に従うか否かについては， 出願人側が責任を負って判断すべきものとなっています。

\section{3 意見書の項目}

意見書の中身，つまり「意見の内容」の部分については， 決まった書式があるわけではありません。しかし，おおよそ 以下のような項目に分けて，記載していきます。意見書，補 正書の具体例については, 特許庁の HPで閲覧注1することが できます。

経緯の説明：審査官の認定について，簡潔に説明します。

補正の説明：特許請求の範囲等の補正の内容と補正の根拠 を説明します。

意見：拒絶理由が解消しているか（存在しないか）の根拠 を説明します。

結言：意見の結論を説明し，再度の審査をお願いします。 なお，補正書によって特許請求の範囲等を補正しない場合 には，上記の項目のうち，補正の説明は省略します。

\section{4 例題の設定}

拒絶理由が，進歩性欠如（特許法第29条第2 項適用）であ る場合には，拒絶理由通知書には，例えば，以下のような認 定が記載されています。

「この出願の請求項 1 の発明は, 下記の引用文献に記載の発 明に基づいて，その出願前に当業者が容易に想到し得たもの であるから，特許法第29条第2項の規定により，特許を受け ることができない。

記

引用文献 1 特開平 $05-\bigcirc \bigcirc \bigcirc \bigcirc \bigcirc$

注1 特許庁HPのJ-Plat-Pat という検索システムを使います。例えば, 「特許・実用新案テキスト検索」によって特定の特許出願を抽 出し, 「審査書類情報」をクリックすることで拒絶理由通知書, 意見書，手続補正書等を閲覧することができます。 
引用文献2 特開昭 58- $\bigcirc \bigcirc \bigcirc \bigcirc$

- 請求項 1

- 理由 1

·方用文献 1

引用文献2

‥ してみると，引用文献 1 に記載された発明に，引用文献 2 に記載された発明を適用することは，当業者が容易になし得 たことである。」

上記のような拒絶理由を解消するには，「本願発明は，引 用文献 1 に記載の発明に基づいて，容易に想到し得たもので はない」ことを主張すればよいことになります。この例では, 引用文献が2つ提示されていますが，通常は引用文献1の方 が重要となります。なぜならば，「進歩性のあり/なし」の認 定の際に, 論理づけの出発点となる引用発明は, 引用発明 1 であるからです。

例えば，請求項 1 の発明（以下，「本願発明 $1 」$ とう。） の構成が以下のようになっているとします。

『本願発明 1 :「12面体のゴム製サイコロ。」

構成（a)：12面体の

構成 $(\mathrm{b})$ ：ゴム製

構成 (c)：サイコロ。」

そして，本願の明細書には，以下のような事項が記載され ていたとします。

\section{『【0007】}

本発明は，子供がゲームで遊ぶ際に使用する 12 面体のゴ ム製サイコロである。双六などのゲームを円滑かつ安全に楽 しむことができる。

\section{【0008】}

従来，子供がゲームで遊ぶ際に使用するサイコロは，丸み を帯びた立方体の硬質樹脂を使用していた。このようにサイ コロは一般的に立方体であるため，転がり難いという欠点が あった。また，サイコロは一般的に硬質樹脂製であるため, ゲームに負けた子供がサイコロを周りの子供に投げつけて怪 我をするというおそれがあった。

\section{【0009】}

そこで，本発明は，ゲームを円滑に進めるために，12面 体のゴム製サイコロを採用した。このサイコロは12面体で あるため，転がり易くゲームを円滑に進めることができる。 また，このサイコロはゴム製であるため，テーブル上でサイ コロが遠くまで弾き飛ばされることがないので，ゲームを円 滑に進めることができる。

\section{【0010】}

また，本発明は，子供がゲームを安全に楽しめるように， 12 面体のゴム製サイコロを採用した。このサイコロは 12 面 体であるため, 双六などのゲームにおいて選択肢が広がり, ゲームを楽しむことができる。また，このサイコロはゴム製 であるため，ゲームに負けた子供がサイコロを周りの子供に 投げつけても怪我をするおそれがない。

\section{【0011】}

また，本発明は，12面体の各平面に数字及び十二支の干 支を描くことが好ましい。12面体の各平面に十二支の干支 を描くことで，サイコロを振ると干支の絵が出ることで，家

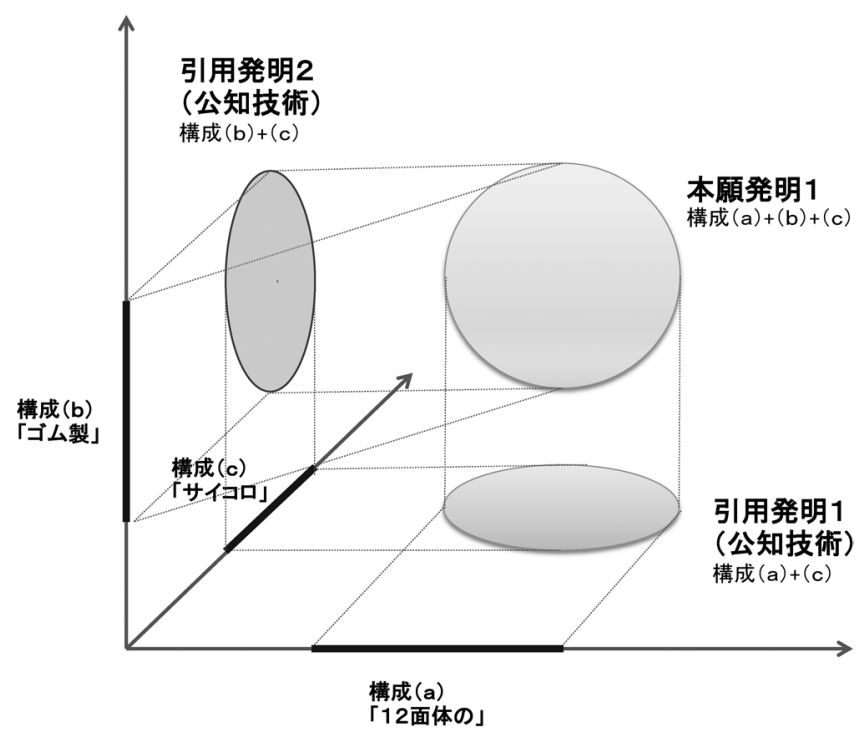

図 5 本願発明 1 と引用発明 1 , 引用発明 2 の関係

族でゲームを楽しむことができる。…

【0020】

サイコロの形状は, 正12面体がより好ましい。サイコロ の材質は，軟質ゴム製がより好ましい。…』

この本願発明 1 に対して, 例えば，引用発明 1 および引用 発明2の構成が以下のようになっているとします。

『引用発明 1 :「12 面体のサイコロ。」(材質：硬質樹脂製）

構成（a)：12面体の

構成 $(\mathrm{c})$ ：サイコロ。

引用発明 2 :「ゴム製サイコロ。」（形状：立方体）

構成 $(\mathrm{b})$ : ゴム製

構成 $(\mathrm{c})$ ：サイコロ。』

この例題で，本願発明 1 と引用発明 1 とを対比すると，一 致点は構成 $(\mathrm{a})+(\mathrm{c})$ であり, 相違点は構成（b）「ゴム製」 となります。特許庁の審査官は, この相違点である構成（b) 「ゴム製」が，引用文献 1 に記載されていないことを認識し ています。そこで，構成（b）「ゴム製」を備えた引用発明2 を記載している引用文献2を提示しています。

この例題では, 引用文献 1 が本願発明 1 に最も近い発明を 開示している，と認定されています。しかしながら，拒絶理 由通知書には引用文献 2 も提示されています。このことは, 引用文献 1 は，本願発明 1 と同一の発明を開示していないこ とを示しています。つまり, 引用文献 1 は, 構成 $(\mathrm{a})+(\mathrm{b})+(\mathrm{c})$ を備える発明を開示しておらず，本願発明 1 は新規性を有す ると認定されているのです。図5に上記例題における本願発 明 1 と引用発明 1 ，引用発明 2 の関係を示します。

図 5 に基づくならば，発明とは，公知技術を言葉で表現し て構成とし，異なる複数の構成を組み合わせて，公知技術に 対して新たな構成を付加して高次元化（=下位概念化）する こととも言えます。ここに公知技術とは，世の中に知られた 技術であり，しかも何人も自由に実施ができる技術のことで す。 


\section{5 論理の構築}

4. 5.1 本願発明 1 と引用発明 1 との対比

まず，本願発明 1 と引用発明 1 とを対比して，構成上の相 違点を明確にします。

例題に当てはめると，例えば以下のようになります。

$\langle$ 相違点〉

本願発明 1 は，「ゴム製」であるのに対して，引用発明 1 は 「硬質樹脂製」である点で相違している。

4.5.2 反論する場合（補正なし）

現在の特許請求の範囲でも十分に反論できそうであれば, 請求項の補正をせずに，意見書にて以下のような主旨で反論 することになります。

4. 5.2.1 本願発明 1 の技術的効果を強調する反論

本願発明 1 の進歩性欠如の認定を覆すために, 本願発明 1 の技術的効果が引用文献 1 の記載からは予期し得ないことを 主張することも有効です。

この例題では，意見書で，例えば，「本願発明 1 は，ゴム 製サイコロであるため, テーブル上でサイコロが遠くまで弾 き飛ばされることがないので，ゲームを円滑に進めることが できます（本願の明細書段落 0009）。これに対し，引用発明 1 では，硬質樹脂製であるため，このような技術的効果を奏 することができません。」と主張することになります。

\section{5.2.2 本願発明 1 の目的を強調する反論}

本願発明 1 の進歩性欠如の認定を覆すために, 本願発明 1 の目的が引用文献1の記載からは想起し得ないことを主張す ることも有効です。この例題では，本願発明 1 を以下のよう に定義しています。

この例題では，意見書で，例えば，「本願発明 1 は，子供 がゲームを安全に楽しめるように、ゴム製サイコロを採用し ています（本願の明細書段落0010）。これに対し，引用発明 1 では，硬質樹脂製であるため，子供が怪我をするおそれが あります。」と主張することになります。

4.5.2.3 動機づけの不存在, 阻害要因の存在等を主張す る反論

この例題では, 引用文献 1 に記載された発明に, 引用文献 2 に記載された発明を適用することが，本当に容易なのか検 討してみる必要があります。本願発明 1 の進歩性欠如の認定 を覆すために，下記(1)〜(6)などの主張がよく採用されていま す。ただし，このような主張をする場合には，特に引用文献 1,2 に記載された事項をよく読む必要があります。

(1)引用発明 1 には, 引用発明 1 に引用発明 2 を適用する ための動機づけがない。

(2)引用発明 1 と引用発明 2 とは技術思想が異なるため組 み合わせることができない。

(3)引用発明 1 に引用発明 2 を適用することは, 理論的に 不可能である。

(4)引用発明 1 には, 引用発明 1 に引用発明 2 を適用する に至る阻害要因がある。

(5)仮に引用発明 1 に引用発明 2 を適用したら, 引用発明 1 が成立し得ない。

(6) 仮に引用発明 1 に引用発明 2 を適用しても, 本願発明 1 に至らない。

この例題では, 引用文献 1,2 の記載内容の具体例について は省略していますので，上記(1)〜6)ような主張の具体例は
割愛します。

\section{5.3 反論する場合（補正あり）}

上記 (1)〜（3）の検討の結果, 現在の特許請求の範囲（請 求項）では, 拒絶理由を解消することが困難であると判断す る場合には, 補正書によって請求項を補正すると同時に, 意 見書にて反論します。

\subsubsection{1 構成による補正を利用する反論}

この例題では, 特許請求の範囲（請求項）を補正する目的 は, 本願発明 1 と引用発明 1 との相違点をより明確にするこ と, あるいは本願発明 1 と引用発明 1 との相違点を新たに追 加することにあります。

例題に当てはめると, 例えば請求項 1 を以下のように補正 することが考えられます。

(1) 本願発明 1 を「12面体の軟質ゴム製サイコロ。」に補 正する。

(2) 本願発明1を「正12面体のゴム製サイコロ。」に補正 する。

(3) 本願発明1を「12面体のゴム製サイコロであって，前 記 12 面体の各平面に数字及び十二支の干支を描いた 12 面体 のゴム製サイコロ。」に補正する。

(3)の具体例では，意見書では，例えば，「本願発明 1 は， 12 面体の各平面に数字及び十二支の干支を描いた 12 面体の ゴム製サイコロというものです。12面体の各平面に数字及 び十二支の干支を描くことで，双六などのゲームにおいて 選択肢が広がり, サイコロを振ると干支の絵が出ることで, 家族でゲームを楽しむことができます（本願の明細書段落 0010, 0011）。引用文献 1, 2 には, 本願発明 1の「12 面体の各 平面に数字及び十二支の干支を描く」という構成は示されて おりません。ㄴしたがって, 当業者が仮に引用発明 1 に引用 発明 2 を適用したとしても, 本願発明 1 に想到することは容 易ではありません。」主張することになります。

4.5.3.2 用途, 目的, 技術的効果等による補正を利用す る反論

上記のようにサイコロそのものの構成について補正する のではなく，明細書中に記載された本願発明の用途，目的， 技術的効果等を利用して本願発明 1 を補正することもできま す。

例題に当てはめると, 例えば請求項 1 を以下のように補正 することが考えられます。

本願発明 1 を「ゲームで遊ぶ際に使用するサイコロであっ て，ゲームを円滑かつ安全に楽しむことができる12面体の ゴム製サイコロ。」

この具体例では, 意見書では, 例えば,「本願発明は, 子 供が双六などのゲームで遊ぶ際に使用するサイコロです（本 願の明細書段落 0007)。本願発明 1 は，12 面体のゴム製サイ コロであるため, 転がりやすく, テーブル上でサイコロが遠 くまで弾き飛ばされることがないので, ゲームを円滑に進め ることができます（本願の明細書段落 0009）。さらに，本願 発明 1 は，12面体のゴム製サイコロであるため, 双六などの ゲームにおいて選択肢が広がり, 安全にゲームを楽しむこ とができます（本願の明細書段落 0010）。引用文献 1,2 には, 本願発明 1 のような「ゲームを円滑かつ安全に楽しむことが できる 12 面体のゴム製サイコロ」は, 示唆も開示もされて おりません。ㄴ.上って, 本願発明 1 は, 引用発明 1,2 に基づ 
いて当業者が容易に想到し得たものではありません。」と主 張することになります。

実際の拒絶理由通知対応ですと，例題（具体例）のように 単純な設定ではありません。拒絶理由通知書に請求項の補正 に関する示唆がある場合には, その示唆に従うのも一案で す。請求項の補正を考慮する際に，当該分野の技術常識など 幅の広い知識が必要とされる場合もあります。いずれにして も, 請求項の補正をうまく利用すると, 反論の説得力は増し ます。

\section{5.おわりに}

発明とは，コロンブスの卵のようなものです。新規性を有 する発明とは，全く新しい技術のことではありません。進歩 性を有する発明とは, 必ずしも難しい技術のことではありま せん。特許発明は, 従来技術に照らして相違点が少なくとも,
その構成の組み合わせに価值があります。特許発明とは, 本 来, 人々の暮らしに役立ち, 産業の発達を促すものである, と思います。本稿が，少しでも読者の皆様のお役に立てるこ とを願っています。最後になりましたが，この原稿を作成す るにあたり，ご監修等を頂きました特許委員会の委員各位， 取りまとめを頂きました日本アルミニウム協会事務局の石川 部長に感謝の意を表します。

\section{参 考 文 献}

1) 産業財産権標準テキスト特許編（第8版），一般社団法人 発 明推進協会, (2014), 41-57.

2）独立行政法人工業所有権情報 - 研修館, INPIT 図 1 工業所有 権情報の役割 http://www.inpit.go.jp/

3) 吉藤幸朔著, 熊谷健一補訂: 特許法概説 (第13版), 有斐 閣, (2001)， 68 .

4) 吉藤幸朔著, 熊谷健一補訂：特許法概説 (第13版), 有斐 閣，(2001)， 111-113. 